\title{
EVALUATION OF SIGNALIZED INTERSECTION PERFORMANCE USING SIDRA AND MKJI 1997
}

\section{Tessar Rizky Permana Nasution}

University of Sumatera Utara, Indonesia

Email: tessarnst@gmail.com

\section{Abstract}

Jl. Brigjen Katamso - Jl. Ir. H. Juanda 4-way Intersection is one of the signalized intersections in Medan. The performance of this intersection decreases along with the increasingly viscous flow of vehicles passing at the intersection. The Level of Service at the intersection is in the F category because the mean intersection delay is more than 60 seconds. To determine the solution to the existing traffic problems, efforts are needed to understand the current traffic system. This study uses a simulation model with SIDRA Intersection Version 8 software to calculate the delays and the Level of Services compared with the 1997 MKJI method calculation data. Based on the 1997 MKJI method, the mean intersection delay is 78.67 seconds with the Level of Services is LOS E. Based on the SIDRA Intersection simulation results, the mean intersection delay is 104.6 seconds with the Level of Services $=$ LOS F. From the calculation results using the MKJI 1997 and SIDRA Intersection, there are differences in the value of the mean delay.

Keywords: Traffic Engineering; Signalized Intersections; Delays; SIDRA Intersection; MKJI 1997

Received: 2021-12-22; Accepted: 2022-01-05; Published: 2022-01-20

\section{Introduction}

Medan, the third-largest city in Indonesia, is the gateway to the western part of Indonesia. This causes urban development and the higher population density of Medan city. The population of Medan city reached 2,435,252 people in 2020 with a population growth rate of $1,45 \%$ per year (BPS Kota Medan, 2020). The development in Medan city is increasing rapidly so various facilities and infrastructure of the city must also be able to serve the needs of the people of this city. One of them is the facilities and infrastructures in the field of transportation that must serve various movements from one place to another with various activities.

The transportation system in Medan is still classified as poor, causing traffic jams, delays, and pollution on various sides of the city. Based on data, the number of motorized vehicles registered in Medan in 2019 reached 275,375 units (BPS Provinsi Sumatera Utara, 2021). Problems with the transportation system in Medan are caused by the imbalance between the ratio of vehicles and road capacity, transportation support facilities such as road markings, crossing bridges, traffic lights, and pedestrian facilities.

\begin{tabular}{ll}
\hline How to cite: & Nasution, T, R, P., (2022) Evaluation of Signalized Intersection Performance Using SIDRA and MKJI 1997, \\
& Syntax Idea, 4(1), https://doi.org/10.36418/syntax-idea.v4i1.1715 \\
E-ISSN: & 2684-883X \\
Published by: & Ridwan Institute
\end{tabular}


Jl. Brigjen Katamso - Jl. Ir. H. Juanda 4-way Intersection is one of the signalized intersections in Medan. The performance of this intersection decreases along with the increasingly viscous flow of vehicles passing at the intersection. The Level of Service at the intersection is in the F category because the average intersection delay is more than 60 seconds (Suriyadi, 2018). It is necessary to evaluate the performance of intersections at the study site based on the average delay value to increase the performance of intersections.

To determine the solution to existing traffic problems requires an effort to understand the current traffic system. This study uses a simulation model with SIDRA Intersection V.8 software to calculate the delay, then compared with the 1997 MKJI method calculation data. Based on the SIDRA Intersection User Guide, SIDRA Intersection is an advanced path-based micro-analytical tool for designing and evaluating intersections and intersection networks, including modeling separate movement classes (light vehicles, heavy vehicles, buses, bicycles, trams, and so on). SIDRA Intersection can estimate capacity, service levels, and various performance measures, including delays, queue length and stops for vehicles and pedestrians, fuel consumption, pollutant emissions, and operating costs (R. Akcelik, 2018).

\section{A. Signalized Intersection Performance}

The performance of an intersection can be seen from several parameters at an intersection (Akbar, 2017), including the following:

1. Capacity, the maximum continuous flow rate at which a vehicle or person can reasonably be expected to traverse a uniform point or segment of a lane or road for a specified period based on a given road, geometric, traffic, environment, and condition control; usually expressed as hourly vehicles, passenger cars per hour, or people per hour.

2. Degree of saturation, the comparison between traffic flow and road capacity.

3. The queue length, the average number of queues in the passenger car unit (pcu) at the beginning of the green signal (NQ) calculated as the number of pcu remaining from the previous green phase $\left(\mathrm{NQ}_{1}\right)$ plus the number of pcu that came during the red phase $\left(\mathrm{NQ}_{2}\right)$.

4. Delay, the additional travel time required to pass an intersection compared to situations without intersections.

5. Level of services, the rounding from the average delay by using the mean delay value as a reference of the level of service.

\section{B. Level of Services}

The level of services of the signalized intersection based on HCM 2000 (Anonymous, 2000) and MKJI 1997 (Manual, 1997) is presented in the following table. 


\section{Table 1}

The Level of Services Classification based on The Average Delay Value

\begin{tabular}{ccc}
\hline \multirow{2}{*}{ Level of Services } & \multicolumn{3}{c}{ Average Delays (sec/pcu) } \\
\cline { 2 - 3 } & HCM 2000 & MKJI 1997 \\
\hline A & $\leq 10$ & $\leq 5,0$ \\
B & $>10-20$ & $5,1-15,0$ \\
C & $>20-35$ & $15,1-25,0$ \\
D & $>35-55$ & $25,1-40,0$ \\
E & $>55-80$ & $40,1-60,0$ \\
F & $>80$ & $>60$ \\
\hline
\end{tabular}

\section{SIDRA Intersection}

SIDRA Intersection is a software developed by Akcelik and Associates Pty Ltd. SIDRA stands for Signalised (and unsignalized) Intersection Design and Research Aid (Fatmawati and Ain, 2021). This program was first released in 1984 (Gundayaini, 2013). The SIDRA program was developed based on the Australian Road Research (ARR 123) method by R.Aceklik.

SIDRA Intersection software uses a detailed traffic analysis model in the form of a lane per lane analysis which is a method of performance analysis by considering each lane and combined with an estimation method to provide estimates of capacity and other performance displays (Ranjitkar et al., 2014; Ali et al., 2018; Sohail et al., 2020). This distinguishes SIDRA Intersection and MKJI 1997, which analyzes with the weaving section method (Frans, 2018).

\section{Critical Movement Method}

The critical movement method was developed on ARR123 standard because of a lack of the phase lost time concept method (Akmaz and Çelik, 2016). According to Akcelik (Rahmi Akcelik, 1981), the phase lost time concept requires a longer effective green time to overcome the following two things:

a. Lost time differences between a movement due to different start loss and end gain values

b. The case of overlap movements, where the intermediate phase intergreen times are green for the movement under consideration.

Understanding the phase lost time concept can be confusing because it is based on the end gain value of the previous movement and the start loss value of the next movement. The movement lost time concept facilitates a clearer understanding of the relationship between movement and signal phasing characteristics. An example of modeling the critical movement method will be explained as follows: 


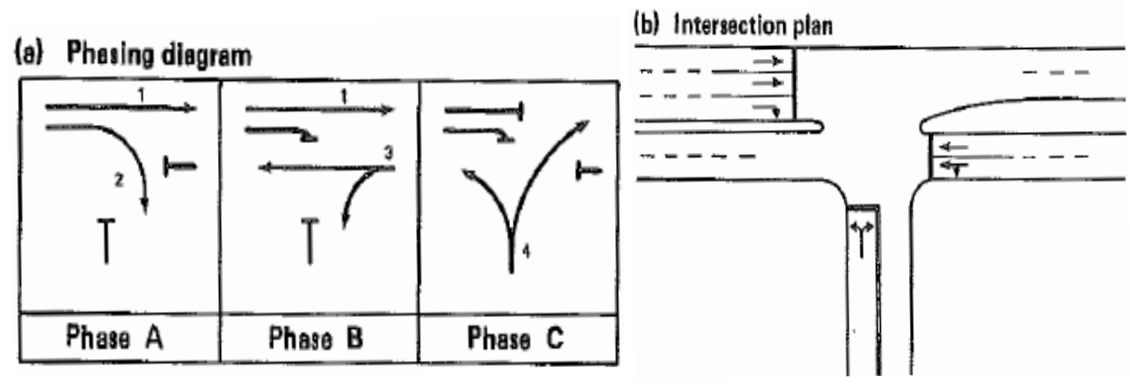

Figure 1

Examples of Phase Diagrams and Intersection Plan

Based on the phase and movement diagrams, it can be tabulated as a table as follows:

Table 2

Phase and Movement Matrix

\begin{tabular}{ccc}
\hline Movement & $\begin{array}{c}\text { Starting } \\
\text { Phase }\end{array}$ & $\begin{array}{c}\text { Terminating } \\
\text { phase }\end{array}$ \\
\hline 1 & $\mathrm{~A}$ & $\mathrm{C}$ \\
2 & $\mathrm{~A}$ & $\mathrm{~B}$ \\
3 & $\mathrm{~B}$ & $\mathrm{C}$ \\
4 & $\mathrm{C}$ & $\mathrm{A}$ \\
\hline
\end{tabular}

The movement data can be illustrated by the movement diagram in the following figure:

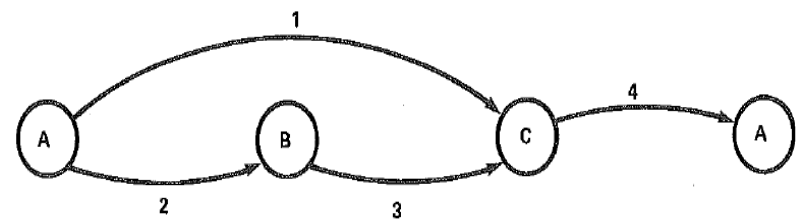

Figure 2

Examples of Critical Movement Search Diagram

Furthermore, the movement that represents critical movement is determined based on the path of movement with the longest time value for one cycle of time and the greatest degree of saturation.

\section{Method}

The step carried out in the study are as follows:

1. The first step is to review and study the literature on textbooks and journals related to traffic engineering, intersection performance, MKJI 1997 method (MKJI, 1997) and SIDRA Intersection simulation (Akcelik, 2018).

2. The second step, collecting data from the intersection of both primary and secondary data.

The data obtained are as follows:

- Road geometric data

- Traffic phase and time cycle data

- Field queue length data

- Traffic volume and type of vehicle 
- Traffic data from related agencies

Primary data collection was carried out during morning rush hour (07.00-08.30) and afternoon rush hour (17.00-19.00) for two weekdays.

3. The third step is analyzing data using the data above based on the MKJI 1997 method and SIDRA Intersection simulation.

4. The fourth step compares the evaluation of intersection performance based on the results of the SIDRA Intersection program simulation and the MKJI 1997 method. The intersection performance is reviewed based on the average delay value of the intersection and the level of Services.

5. The fifth step, at this stage, analyzes the results of the intersection performance of the calculations and simulations carried out and makes conclusions and suggestions.

\section{Results and Discussions}

Observation data is primary data that will be used to calculate the intersections for existing conditions. Data observed in the field include intersection geometric data, phase and cycle times, and traffic flow volumes. The data will then be evaluated using the MKJI 1997 method and the SIDRA Intersection program.

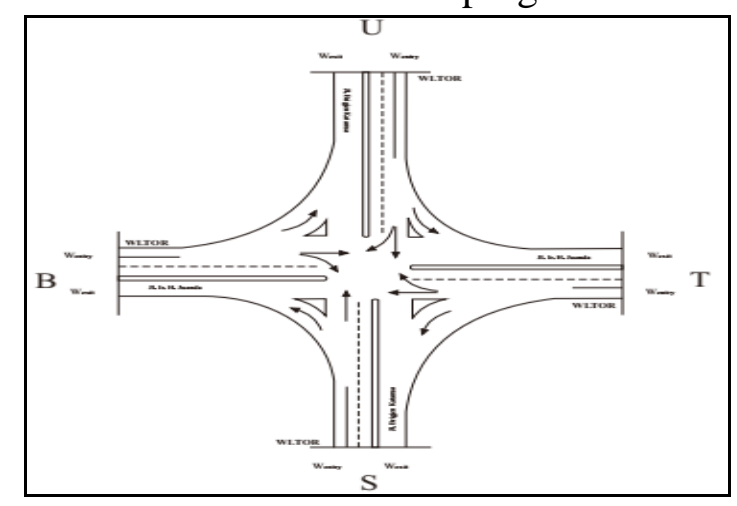

Figure 3

Intersection Geometric

Table 3

Intersection Geometric Data

\begin{tabular}{lcccc}
\hline \multicolumn{1}{c}{ Approach } & Northern & Eastern & Southern & Western \\
\hline Area Type & Commercial & Commercial & Commercial & Commercial \\
\hline Side Frictions & Moderate & Moderate & Moderate & Moderate \\
\hline Strip Island & Yes & Yes & Yes & Yes \\
\hline Strip Island Width $(\mathrm{m})$ & 1,7 & 1,2 & 2 & 1,2 \\
\hline Left Turn On Red & Yes & Yes & Yes & Yes \\
\hline Approach Width & 9 & 15 & 9,5 & 15,8 \\
\hline Entry Approach Width $(\mathrm{m})$ & 6,3 & 11 & 7 & 11,4 \\
\hline LTOR Approach Width $(\mathrm{m})$ & 2,7 & 4 & 2,5 & 4,4 \\
\hline Exit Approach Width $(\mathrm{m})$ & 8,3 & 7,7 & 7,8 & 11 \\
\hline
\end{tabular}


The intersection in this study is located in a commercial area with moderate side friction. The entire intersection arm has strip islands and traffic signals to separate the traffic flow paths. The entry and LTOR approach width is greatest at the west and east intersection arms because traffic from this direction has the largest flow volume.

Table 4

\section{Traffic Cycle Phase}

Phase Sequence

CRITICAL MOVEMENT DIAGRAM
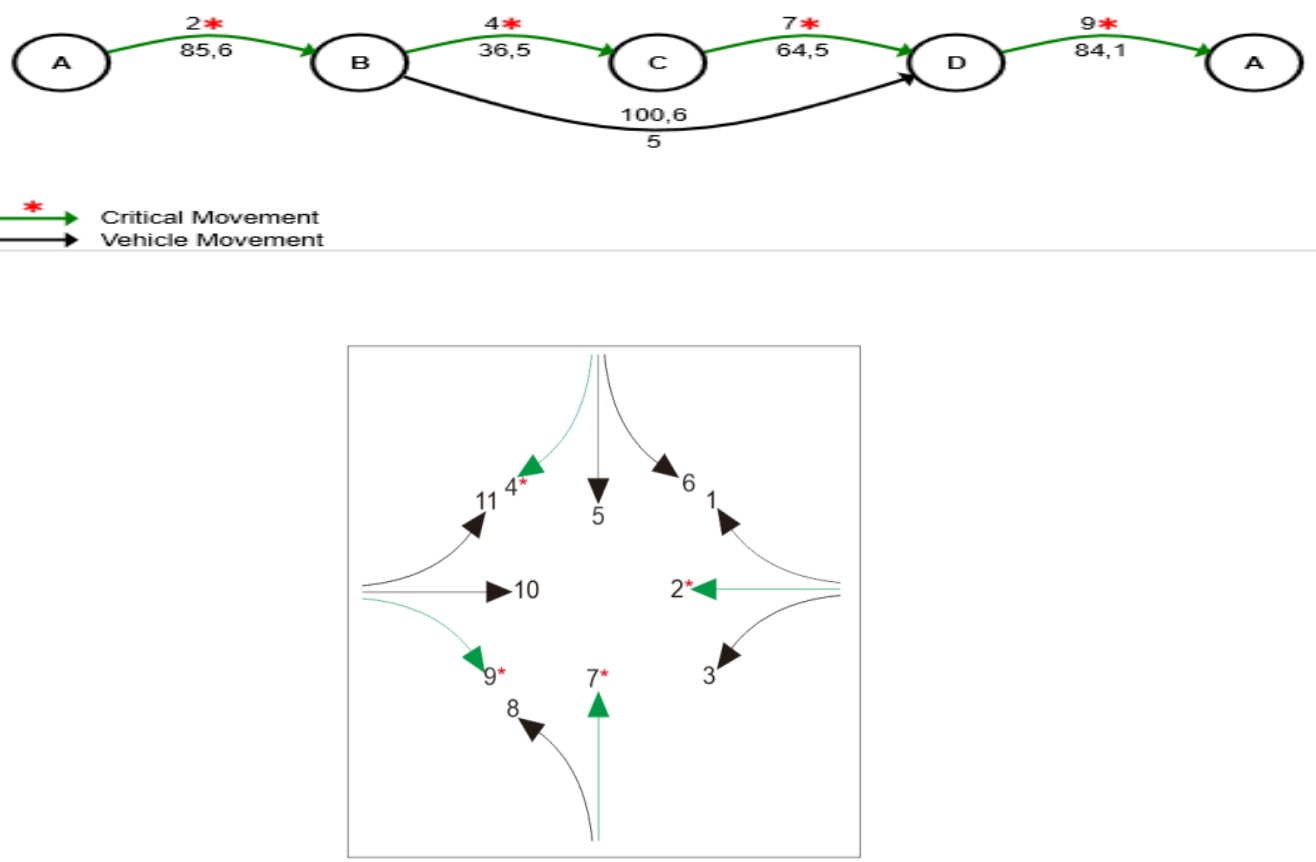

Figure 4

Critical Movement Diagram and Traffic Movement Direction

Table 4 and figure 4 show traffic cycles at intersections. The intersection phase cycle consists of 4 phases starting from the east (movements 1, 2, and 3), followed by north (movements 4,5, and, 6), south (movements 7 and 8), and west (movements 9, 10, and 11). The results of the SIDRA program processing show that the critical movement of the intersection occurs in the flow or movement at numbers $2,4,7$, and 9. 
Table 5

Traffic cycle time (Morning Rush Hour)

\begin{tabular}{lcccc}
\hline Approach & $\begin{array}{c}\text { Red } \\
\text { phase } \\
\text { (sec) }\end{array}$ & $\begin{array}{c}\text { Yellow } \\
\text { phase } \\
\text { (sec) }\end{array}$ & $\begin{array}{c}\text { Green } \\
\text { phase } \\
\text { (sec) }\end{array}$ & $\begin{array}{c}\text { Cycle } \\
\text { time } \\
\text { (sec) }\end{array}$ \\
\hline Northern & 136 & 2 & 142 & 280 \\
\hline Eastern & 218 & 2 & 60 & 280 \\
\hline Southern & 172 & 2 & 106 & 280 \\
\hline Western & 212 & 2 & 66 & 280 \\
\hline
\end{tabular}

Table 6

Traffic cycle time (afternoon rush hour)

\begin{tabular}{lcccc}
\hline Approach & $\begin{array}{c}\text { Red } \\
\text { phase } \\
(\mathbf{s e c})\end{array}$ & $\begin{array}{c}\text { Yellow } \\
\text { phase } \\
(\mathbf{s e c})\end{array}$ & $\begin{array}{c}\text { Green } \\
\text { phase } \\
(\mathbf{s e c})\end{array}$ & $\begin{array}{c}\text { Cycle } \\
\text { time } \\
(\mathbf{s e c})\end{array}$ \\
\hline Northern & 197 & 2 & 116 & 315 \\
\hline Eastern & 265 & 2 & 48 & 315 \\
\hline Southern & 237 & 2 & 76 & 315 \\
\hline Western & 174 & 2 & 139 & 315 \\
\hline
\end{tabular}

Tables 5 and 6 show traffic cycle times at intersections during the morning and evening rush hours. There is a difference in cycle time between the two peak hours, where the afternoon peak clock cycle time (315 seconds) is higher than the morning peak clock cycle time (280 seconds).

Table 7

Traffic Volume Data

\begin{tabular}{cccccc}
\hline \multirow{2}{*}{ Period } & \multicolumn{4}{c}{ Queue Length $(\mathbf{m})$} \\
\cline { 3 - 6 } & & $\mathbf{N}$ & $\mathbf{E}$ & $\mathbf{S}$ & $\mathbf{W}$ \\
\hline \multirow{2}{*}{$30-$ Sep-19 } & $07.00-08.30$ & 79.6 & 176.9 & 364.3 & 129.1 \\
\cline { 2 - 6 } & $17.00-19.00$ & 84.1 & 179.5 & 369.4 & 126.6 \\
\hline \multirow{2}{*}{$01-$-Oct-19 } & $07.00-08.30$ & 123.3 & 181.4 & 190.6 & 307.9 \\
\cline { 2 - 6 } & $17.00-19.00$ & 117.8 & 184.5 & 182.5 & 299.2 \\
\hline \multicolumn{2}{c}{ Average } & 101.2 & 180.6 & 276.7 & 215.7 \\
\hline
\end{tabular}

Table 7 shows the traffic volume at the intersection. The highest traffic volume during the morning rush hour occurs at 07.15 to 08.15 , while the highest traffic volume during peak hours occurs at 17.45 to 18.45 . The highest traffic volume during the morning rush hour comes from the southern approach, while the highest during the afternoon rush hour comes from the western approach. This is caused in the morning, the traffic flow from outside the city comes from the south, and in the afternoon, the return flow from the city center is on the western approach. 
Table 8

Field Queue Length Data

\begin{tabular}{lc}
\hline \multicolumn{1}{c}{ Parameter } & MKJI 1997 \\
\hline Capacity (pcu/h) & 4895.28 \\
Degree of Saturation & 0.85 \\
Average Delays (sec) & 78.675 \\
Level of Services & $\mathrm{F}$ \\
\hline
\end{tabular}

\section{MKJI 1997 Method Result}

The intersection performance evaluation is based on SIG-I (Geometric, traffic, and environmental regulation), SIG-II (Traffic flow), SIG-IV (Determination of signal time and capacity), and SIG V (length of queues, number of vehicles stopped, and delays). The results of calculating the form using the 1997 MKJI method, it is recapitulated in the following table:

Table 9

\begin{tabular}{lc} 
Intersection Performance using MKJI 1997 Method Summary \\
\hline \multicolumn{1}{c}{ Parameter } & SIDRA Intersection \\
\hline Capacity (pcu/h) & 1082.9 \\
Degree of Saturation & 0.945 \\
Average Delays (sec) & 104.6 \\
Level of Services & $\mathrm{F}$ \\
\hline
\end{tabular}

The calculation results of using the 1997 MKJI method show that the intersection is 4895.28 vehicles per hour. The comparison between the traffic volume load and the traffic capacity (degree of saturation) at the intersection is 0.85 . Traffic with thus degree of saturation can be described as a traffic flow that is unstable and stops frequently. The average delay reaches 78,675 seconds (>60 seconds) so it has a level of services F.

2. SIDRA Intersection Simulation Result

The performance evaluation of intersections is simulated using SIDRA Intersection V.8 and the standard ARR123 method. The optimal cycle time and capacity is determined using the Critical Movement Method and the value of the base saturation current in ARR123. The results of the SIDRA Intersection simulation are further summarized in the following table:

Table 10

Intersection Performance using SIDRA Intersection Simulation Summary

\begin{tabular}{cc}
\hline Parameter & SIDRA Intersection \\
\hline Capacity $(\mathrm{pcu} / \mathrm{h})$ & 108829 \\
\hline Degree of Saturation & 0.945 \\
\hline Average Delays (sec) & 104,6 \\
\hline Level of Services & $\mathrm{F}$ \\
\hline
\end{tabular}


The calculation results of using the SIDRA Intersection method show that the intersection is 10,282.90 vehicles per hour. The comparison between the traffic volume load and the traffic capacity (degree of saturation) at the intersection is 0.945 . Traffic with thus degree of saturation also can be described as a traffic flow that is unstable and stops frequently. The average delay reaches 104,6 seconds (>60 seconds) so it has a level of services $\mathrm{F}$.

\section{Conclusion}

Based on field observations and calculations using the MKJI 1997 and SIDRA intersection, the conclusions are as follows, (1.) The largest traffic flow during the morning rush hour occurs in the south direction approach is 1290,4 pcu, while for the traffic flow during the afternoon rush hour occurs in the west direction approach is 2274,6 pcu. (2.) Based on observations, it can be seen that the average delay value using SIDRA Intersection simulations tends to be greater than the average delay value using the MKJI 1997 method. The average delay value in the MKJI 1997 method is 78,675 seconds and the SIDRA Intersection simulation is 104,6 seconds. (3.) Intersection performance can be evaluated with the intersection level of services. Based on the calculation results of the MKJI 1997 method and the SIDRA Intersection simulation, there was no difference in the level of intersection services (LOS F in the MKJI 1997 and SIDRA Intersection methods).

\section{BIBLIOGRAFI}

Akbar, S. J. et al. (2017). Re-planning the Traffic Management System from Three Phases to Four Phases. Teras Jurnal, Vol.7, No.1, March 2017.

Akcelik, R. (2018). SIDRA Intersection User Guide. Akcelik \& Associates Pty.Ltd.

Akcelik, Rahmi. (1981). Traffic signals: capacity and timing analysis. Google Scholar

Akmaz, M. M., and Çelik, O. N. (2016). Examination of Signalized Intersections According to Australian and HCM (Highway Capacity Manual) Methods Using Sidra Intersection Software. Journal of Civil Engineering and Architecture 10 (2016) 246-259. Google Scholar

Ali, S. I. A., Rifat R. and Hudaverdi T. (2018). Evaluation and Analysis of Traffic Flow at Signalized Intersections in Nicosia Using of SIDRA 5 Software. Jurnal Kejuruteraan 30(2) 2018: 171-178. Google Scholar

Anonymous. (2000). Highway Capacity Manual (HCM), Transportation Research Board, Washinton D.C.

BPS Kota Medan. (2020). Kota Medan Dalam Angka 2021. Badan Pusat Statistik Kota Medan. Google Scholar 
Tessar Rizky Permana Nasution

BPS Provinsi Sumatera Utara (2021). Provinsi Sumatera Utara Dalam Angka 2020. Badan Pusat Statistik Provinsi Sumatera Utara.

Fatmawati and Mohammad, I. M. A. (2021) Evaluasi Kinerja Simpang Empat Bersinyal dengan Metode MKJI dan Sidra Intersection. Borneo Engineering: Jurnal Teknik Sipil Vol. 5 No.1 April 2021. Google Scholar

Frans, J. H. et al. (2018). Planning and Performance of the Roundabout Based on the 1997 MKJI Method and Sidra Intersection V5.1. Journal of Civil Engineering, Vol. VII, No. 2, September 2018.

Gundayaini, Y. A. (2013). Evaluation of Performance of Signalized Intersections Due to the Application of 4 in 1 (Case Study of the Sumantri Surya Intersection Dr.Djunjunan). Journal of the Bandung Institute of Technology Publications.

Manual, Indonesian Highway Capacity. (1997). Directorate general of highways. Ministry of Public Works, Jakarta. Google Scholar

Ranjitkar. P., Amin. S., and Fasihullah S. (2014). Evaluating Operational Performance of Intersections Using SIDRA. The Open Journal, 2014, 8, 50-61. Google Scholar

Sohail, M. S., Mir I. F., and Mohd M. A. (2020). Performance Analysis of a Roundabout using Sidra Intersection Software. International Journal of Research and Analytical Reviews (IJRAR). Volume 7, Issue 2 June 2020.

Suriyadi. (2018). Evaluation of the Implementation of the Advanced Stop Lines (ASL) of Motorbikes at Signed Intersections (Case Study: Intersection of Jl Ir.H.JuandaBrigjen Katamso, Medan). Medan. USU Institution Repository.

\section{Copyright holder:}

Tessar Rizky Permana Nasution (2022)

First publication right:

Syntax Idea

This article is licensed under:

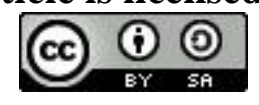

